\title{
Registration fee payment optimization for students received educational loan (the case of Suan Sunandha Rajabhat University, Bangkok, Thailand)
}

\author{
Yanika Pinit ${ }^{1, *}$, and Kongsak Boonarchatong ${ }^{1}$ \\ ${ }^{1}$ International College, Suan Sunandha Rajabhat University, 1 U-Thong Nok rd, 10200, Dusit, \\ Bangkok, Thailand
}

\begin{abstract}
The study is devoted to the development of methods for determining the social acceptability of tuition fees in universities. The objectives are 1) to investigate how to increase the efficiency of student loan management in Suan Sunandha Rajabhat University, and 2) to create guidelines for improvement and development of routine works for Student Loan Funds Department. This study is conducted via a survey research methodology. The sample 440 students who pay tuitions fees, includes ones with Students Loan. The quantitative data were analyzed using descriptive statistics of frequency, percentage, and average. The contribution for this study is to provide suggestion to improve and develop the channel to keep tracking the students having the outstanding fees, the difference in tuition fees, to pay for the outstanding tuition fees in order to reduce the number of outstanding fees in the system.
\end{abstract}

\section{Introduction}

Education has been mentioned as the foundation of the human development to enhance the quality of working and daily life for surviving with the changes in the globalization era. Therefore, providing the educational opportunities to develop people is very necessary. A quality education should provide a chance to enable each person's potential to be fully developed as a person with a mind, wisdom, knowledge, morality, ethic and culture to live happily with others [1].

Most countries of the world, both developed and developing, provide higher education services, regardless of the form of the university ownership, only on a fee basis [2]. World practice shows that in recent years there have been significant, albeit uneven and ambiguous changes, according to which the cost of training, which had previously been borne mainly by the government or taxpayers, will now be shared between parents and students. This situation is explained, firstly, by the need for non-state sources of financing.

\footnotetext{
Corresponding author: yanika.pi@ssru.ac.th
} 
Due to the demographic growth of applicants to universities, as well as due to an increase in the number of middle-aged people who have not previously received higher education and intend to compensate for this omission, the demand for higher education (both public and private sectors), which is considered as the main engine state economic growth and the guarantee of individual welfare opportunities has increased markedly. Secondly, tuition fees in the developed countries of the world are the price of expensive and highly sought after goods, which provide guarantees of employment and high earnings, as well as the possibility of political growth.

Currently, inequality in education is one of the problems making people unable to access education. One of possible ways to handle the education inequality is to establish the Student Loan Funds for students lacking of money for tuition fee and education expenses. The Student Loan Funds give authority for education institutions to carry out the lending funds.

The study is devoted to the development of methods for determining the social acceptability of tuition fees in universities.

The purpose of the study is to solve the following problems:

1 How to keep in a socially acceptable framework the process of commercialization of higher education services?

2 How to adapt the traditional university budget model to the specific conditions of the Thai market within the framework of the current legislation and the existing level of state funding?

3 How to determine the social acceptability of the level of payment for services of higher professional education, without causing social tension in a market economy?

Following tasks were solved:

- An analysis of the principles of paid education in Thailand and abroad;

- The concepts of social acceptability and factors influencing it are defined;

- A methodology has been developed for assessing the social acceptability of setting fees for educational services.

\section{Literature reviews}

Based on the analysis of global trends in the formation of educational fees the author was able to establish the following:

In Thailand, there is a tendency to determine fees for higher professional education on the basis of an expensive pricing model: the costs of an educational institution are more or less methodically competently calculated and tuition fees are established on their basis [3].

In Thailand, serious consumers of educational services gradually understand the necessity and even desirability of setting fees for higher professional education as a source of competitiveness in the labor market. However, the society is still heterogeneous in the opinion that the further shift in the costs of higher professional education to students and families is correct, necessary, or at least logical. The transition from the idea that higher education should be free to the need to introduce tuition is very difficult, although in fact education is becoming paid.

A number of countries of the world, including China, countries of Southeast Asia, Latin America, Eastern and Central Europe, as well as industrially developed countries of the West, demonstrate approaches of the neoliberal economy in matters of financing education. This means that the priority of state support for higher education is significantly complemented by an increase in the cost of education on the part of students and their family budgets. A situation in which parents and students will incur increased costs is both inevitable and economically justified. 
Paid higher education has become a fait accompli in most countries of the world and is becoming more common in Thailand. However, the principles of its establishment do not have a clear methodological justification.

A number of foreign sources pay particular attention to determining the availability of higher professional education, but basically it all comes down to providing poor students with all kinds of benefits and allowances, rather than establishing a reasonable level of tuition.

The social status of education is determined by various factors.

All factors determining the social status of education can be divided into three groups:

- Factors related to material well-being

- Factors related to the image of a person

- Factors related to competitiveness of an individual

As known, all benefits are divided into three groups: private goods, club goods and public goods.

Private goods are acquired for money and become the property of the buyer.

Club benefits to an official circle of persons who possess certain attributes that unite them. They are available, but more often than not free.

Public goods include those that in most cases are free and affordable, but the level of quality provided by the state is not always acceptable to the consumer. In a socially oriented market economy, the consumer must have sovereignty when choosing the nature of public, club or private.

Education in most countries of the world is a public good. But the social nature of this good depends on what level of education is being considered. In most countries of the world, higher education is not free, although, as education, it belongs to the sphere of public goods.

The accessibility of higher professional education provides the possibility of receiving it to capable, but low-income citizens.

Middle-income citizens should be able to pay for education (theirs or their loved ones) in the amount available to them, as they pay for all kinds of private benefits. Therefore, a very urgent task is to determine not so much the amount of tuition fees in general, but the size of a socially acceptable education. Obviously, in such conditions, higher professional education ceases to be fully public, acquires the features of a private good.

Thus, the relevance of determining the socially acceptable payment for higher education seems quite obvious. This approach allows you to combine the principle of accessibility of higher education with the principle of payment.

Social justice in the field of higher professional education is characterized by its free competition for all citizens, as it is written in the Constitution. Accessibility does not necessarily mean free. Pay can also be affordable if the pay is socially acceptable. The sphere of higher education as a public good can be outlined by a list of specialties necessary for the reproduction of public goods. The sphere of higher education as a club good is outlined by the specifically expressed needs of employers who are interested in specialists of a specific profile.

The sphere of higher education as a private good is outlined by the needs of citizens, which are based on their own ideas about the need for specialists in the labor market and personal interests and preferences.

Of particular theoretical significance is the relationship between the concepts of "price of educational services" and "tuition fees". For the consumer of educational services, any tuition is perceived as the price of a certain product. For the producer of educational services in the context of social acceptability, payment of educational services is not a price, since it does not fully cover its costs. Therefore, for the producer, the money received 
from the client in the economic aspect is only part of the cash flow that compensates for its costs of organizing and conducting the educational process.

Many researchers investigate various aspects of Student Loan Funds such as behaviours and problems of using the funds, assessment the operations of the funds and the satisfaction of the services of the Student Loan Funds, as seen following;

[4] investigated the behavior and problems of spending on educational loan funds of students in the Faculty of Industrial Education, King Mongkut's Institute of Technology Ladkrabang. The objective of the research is to study the behavior and problems caused by spending on Student Loan Funds. The results have shown that the behavior of the use Student Loan Funds of the Faculty of Industrial Education King Mongkut's Institute of Technology Ladkrabang, classified by gender, subject and student year level, is at a low level. The behavior of spending on funds from the highest to lowest average to as follows: education expenses and living expenses study during their study respectively.

Ekaphop studied the evaluation of the operation of the Student Loan Funds for Higher Education in Chiang Mai. The aims of the research are to evaluate the Student Loan Funds in terms of increasing educational opportunities, the ability to handle educational expenses, study of the economic and social conditions of loan recipients, and study the problems and suggestions on the fund management. It depicted that the fund has increased educational opportunities for students at $89.36 \%$, increasing educational opportunities in public and private educational institutions, at $89.12 \%$ and $84.09 \%$, respectively. The Student loan funds also has increased educational opportunities at the level of Bachelor and the vocational certificate level, which is at $97.28 \%$ and $76.56 \%$, respectively [5].

[6] examined the student satisfaction of students receiving the Student Loan Funds at Mahidol University. The objectives of the research are to study the satisfaction of students towards the use of the Student Loan Fund, Mahidol University, and to find weaknesses and strengths and opportunities for the development of the Student Loan Funds services and suggestions for the services. It was found that the students' satisfaction on the use of the Student Loan Funds, Mahidol University, in all 5 areas, is at a high level.

The students' satisfaction on the use of the Student Loan Fund Services, Mahidol University, classified by gender, age and student year level, has different levels of satisfaction. Suggestions of this research are to improve public relations by increasing public relations channels and direct to students. The service personnel must be polite, attentive, and promptly and accurately assistant. In terms of the location of the service, there is an increase in service hours for students in the evening, and the faculty is assigned to enhance convenience and speed and to avoid congestion in the service areas. The research conducts the development of forms and operational guidelines for providing educational loan funds for students to access services and increase students' satisfaction.

[7] investigated the satisfaction of students towards the administration of Suan Sunandha Rajabhat University. The aims of the research are to study the satisfaction of students to the administration of Suan Sunandha Rajabhat University and to be as a guideline for improvement and correction of the administration of Suan Sunandha Rajabhat University. The results show in two aspects as following; Firstly, the teaching and learning management of the university are the teaching and learning curriculum, teachers, media / teaching aids and locations for teaching and learning. Secondly, the university's services are academic services, general services and thesis / dissertation services (only for graduate students).

\section{Methodology}

The Student Loan Funds job at Suan Sunandha Rajabhat University, Student Loan Funds and Income Continent Loan (ICL) is managed by the Education Fund Department and the 
Finance Department, Finance Division. The Finance Department run the process from providing the records to correctly control the number of students getting loans and money, making tuition fees payment of the students and transferring money into the university income.

However, there is a special problem case because of the students getting loans with tuition fee exceeding the full loan rate. This is the problem in the process because the students have to pay the difference of the accepted loan and the tuition fee. However, they do not pay the difference in the stipulated time according to each semester, resulting in the outstanding money in the account and the occurrence of interest, which is against the rules of the Student Loan Funds.

The key success factors of the ability to access the service from the Student Loan Funds are the service rate, satisfaction rate, ease of travel to receive service, communication and public relations, service quality and service management [8].

Therefore, the researcher intends to study on methods or channels to contact students in case of having to pay the tuition fee difference as much as possible. This study will be used as a guideline to improve and develop services to increase the management efficiency on the Student Loan Funds of the Finance Department.

This study is conducted via a survey research methodology and questionnaires are used as a tool for collecting data.

For determination of priorities and conditions for Thailand students' loan system improvement we realized a survey of 440 presenters of Thai young generation (students of the International College at Suan Sunandha Rajabhat University in Bangkok). Student's personal data is in the Table 1.

Table 1. Personal data about surveyed students (made by co-authors).

\begin{tabular}{|c|c|c|c|c|}
\hline Groups & \multicolumn{2}{|c|}{ Younger than 20 y.o. } & $\begin{array}{c}\text { Older than } \\
\mathbf{2 0} \text { y.o. }\end{array}$ & \multirow{2}{*}{ Totally } \\
\hline \multirow{3}{*}{ Male } & From Bangkok & 12 & 62 & \multirow{2}{*}{140} \\
\cline { 2 - 4 } & Out of Bangkok & 18 & 48 & \\
\cline { 2 - 4 } & & 30 & 110 & \\
\hline \multirow{3}{*}{ Female } & From Bangkok & 20 & 130 & \multirow{2}{*}{300} \\
\cline { 2 - 4 } & Out of Bangkok & 16 & 134 & \\
\cline { 2 - 4 } & \multicolumn{3}{|c}{} & 264 \\
\hline Totally & \multicolumn{3}{|c}{440} \\
\hline
\end{tabular}

\section{Results and discussion}

The survey results are presented in Table 2.

Analysis of financial satisfaction in a reduced sample (only those individuals who had student loan debt) was conducted using two-step estimation method (Table 2) $[9,10]$ to delve further into aspects related to student loan debt. The first stage employed a probit model to predict whether a respondent had any student loan debt. The second stage explored financial satisfaction based on the different loan sources specified in the survey, conditional on an individual having student loan debt in the first step of the regression. For the present model, the second stage of the Heckman estimation was analogous to OLS given the nature of the dependent variable, financial satisfaction.

Among demographic and socioeconomic characteristics, older respondents were less likely than those in the 20-24 years old age group to have student loan debt.

Compared to those with educational attainment of high school or less, attainment of some college, college, or higher levels of education was positively associated with having 
student loan debt. Generally, respondents with incomes greater than 450,000 THB were less likely to carry student loan debt than those with income less than 450,000 THB.

Table 2. Results of two-stage Heckman specification (made by co-authors).

\begin{tabular}{|c|c|c|}
\hline Variables & $\begin{array}{l}\text { Stage 1: probit analysis } \\
\quad \text { for } 20+\text { yo sample } \\
\text { Estimate (standard error) }\end{array}$ & $\begin{array}{c}\text { Stage 2: OLS regression for } \\
\text { respondents with student loan } \\
\text { debt } \\
\text { Estimate (standard error) }\end{array}$ \\
\hline \multicolumn{3}{|l|}{ Student loans } \\
\hline \multicolumn{3}{|l|}{ Loan source } \\
\hline Private only & & $0.483 * * *(0.101)$ \\
\hline Both government and private & & $-0.089(0.080)$ \\
\hline $\begin{array}{l}\text { Satisfaction with previous } \\
\text { student loan choice }\end{array}$ & & $0.183 * *(0.073)$ \\
\hline Income-based repayment plan & & $0.138(0.075)$ \\
\hline \multicolumn{3}{|l|}{ Financial attitudes } \\
\hline Risk tolerance & $0.008(0.007)$ & $0.254 * * *(0.017)$ \\
\hline Worry about retirement & $-0.023 *(0.009)$ & $-0.036(0.022)$ \\
\hline \multicolumn{3}{|l|}{ Self-reported credit record } \\
\hline Worse than average & $-0.108 *(0.055)$ & $-0.442 * * *(0.112)$ \\
\hline Better than average & $-0.124 * *(0.043)$ & $0.098(0.100)$ \\
\hline Have too much debt & $0.189^{* * *}(0.008)$ & $-0.077(0.062)$ \\
\hline \multicolumn{3}{|l|}{ Financial behaviors } \\
\hline \multicolumn{3}{|l|}{ Spending behavior } \\
\hline Spend less than income & $0.025(0.035)$ & $0.036(0.083)$ \\
\hline Spend more than income & $0.023(0.042)$ & $-0.222 *(0.091)$ \\
\hline Have emergency fund & $-0.031(0.038)$ & $0.758^{* * *}(0.087)$ \\
\hline Have a budget & $0.063(0.033)$ & $0.061(0.082)$ \\
\hline Have planned for retirement & $0.031(0.035)$ & $-0.168 *(0.081)$ \\
\hline Have savings account & $0.078(0.044)$ & $0.303^{* *}(0.104)$ \\
\hline Own home & $-0.185 * * *(0.036)$ & $0.325 * * *(0.097)$ \\
\hline
\end{tabular}

Financial risk tolerance was positively associated with the likelihood of obtaining a student loan and with financial satisfaction. Previous research has shown that higher risk tolerance is associated with risky borrowing behavior among households [11]. Risk-tolerant households may be less sensitive to the potential costs of education borrowing and more optimistic about their future prospects. In general, the findings revealed that having financial assets was positively associated with financial satisfaction and that financial strain was negatively associated with financial satisfaction mirror those from previous research $[12,13]$.

Experiencing a financial shock, financial fragility, difficulty meeting expenses, and having a worse-than-average self-reported credit record were negatively associated with financial satisfaction. Financial fragility, difficulty meeting expenses, and a worse-thanaverage credit record also were negatively associated with financial satisfaction among respondents who carried some student loan debt.

Interestingly, the behaviors of taking a loan or hardship withdrawal from retirement (indictors of financial strain) were positively associated with financial satisfaction. This may be due to the fact that such actions provide needed relief to a household, even when that relief means that future satisfaction may be adversely impacted.

Since there is no way to control for the timing of these decisions, it is difficult to understand the exact pathways that may be at work. 


\section{Conclusions}

As a result of the study, it has been established that the share of income of state universities received from students in foreign countries is on average $10-25 \%$. This value is used as a norm for Thailand, since it characterizes the level of social acceptability of tuition at universities in foreign countries.

In other words, if we transfer the majority of the university's expenses to students and their parents, this will mean that Thai students are in worse conditions than their peers abroad and can serve as a basis for manifesting social discontent, in other words, this situation will not be social acceptable.

One key finding from this study was that student loans received through private and a combination of government and private sources were negatively associated with the respondents' willingness to repeat the same borrowing behavior.

The results remain somewhat mixed, however, since having student loan debt was not negatively associated with financial satisfaction as hypothesized. Student loan debt is unique from other forms of debt in that it is an investment in human capital and is associated with a steeper earnings path that would result in greater satisfaction overall.

Results from the analysis of choice satisfaction indicated that regret on the part of many borrowers could be a significant issue of concern. The results do not provide a clear direction for recommendations about acquiring student loans from multiple sources. Whereas borrowers who took out both private and federal student loans reported lower satisfaction with past borrowing decisions, having multiple sources did not significantly influence their financial satisfaction.

Perhaps future research could provide insights to inform policy makers about creating disruptions in the student loan market, such as Income Share Agreements, which provide funding for education repaid based on a fixed percentage of the student's post-college income for a fixed number of years. The current results raise further questions over the proper policy response. Some have proposed a shift to repayment schemes that are incomebased as a default [14].

Such a change could possibly reduce the financial strain for younger households starting out. However, the current results lack the detail about the timing of loan pay-offs or the magnitude of the debt held that would be needed to examine this question in detail. In effect, we find only modest support for the popular arguments alluding to a student loan crisis.

\section{References}

1. Office of the National Education Commission (The $8^{\text {th }}$ National Education Development Plan. Bangkok, 1997).

2. D. Ushakov, Research Journal of Business Management 5(4), 159 (2011).

3. A. Sivkova, N. Kazakova, EUrASEANs 2(9), 68 (2018)

4. K. Boonyapak, To Study Behavior and Ploblem Loans Usage Solutions in Faculty of Industrial Education of King Mongkut's of Institute Technology (King Mongkut Institute of Teachnology, Bangkok, 2008).

5. E. Poomara, Evaluation of the Student Loans Fund for Higher Education in Chaing Mai (Srinakharinwirot University, Bangkok, 2010).

6. U. Panboonhom, Survey of Student Satisfaction towards the service of the student loan (Mahidol University, Bangkok, 2017). 
7. B. Santhan, The students' satisfaction toward the management of Suan Sunandha Rajabhat University (Suan Sunandha Rajabhat University, Bangkok, 2012).

8. R. Jungkitcharoenphaisan, The Study on "Developing the Method of Assisting Student Loans for Tuition Fees of Thammasat University (Thammasat University, Bangkok, 2009).

9. J. Heckman, Annals of Economic and Social Measurement 5(4), 475 (1976).

10. J. Heckman, Econometrica 47(I), 153 (1979).

11. V. Zahirovic-Herbert, K. Gibler, S. Chatterjee, Intern. J. of Housing Markets and Analysis 9(2), 164 (2016).

12. W. Disch, L. Harlow, J. Campbell, T. Dougan, Social Indicators Research 51(1), 41 (2000).

13. A. Woodyard, C. Robb, Journal of Financial Therapy 7(2), 41 (2016).

14. S. Dynarski, An economist's perspective on student loans in the United States (Brookings Institute ES Working Paper Series, 2014). 